\title{
Two Years Monitoring of Ethyl Carbamate in Sugar Cane Spirit from Brazilian Distilleries
}

\author{
Rafaela C. Bueno, ${ }^{a}$ Angélica P. P. Tonin, ${ }^{a}$ Camila B. Poliseli, ${ }^{a}$ Nayane B. M. Sinosaki, ${ }^{a}$ \\ Claudio C. Oliveira, ${ }^{a}$ Jesuí V. Visentainer, ${ }^{\circledR a}$ Marcos A. S. Ribeiro, ${ }^{a}$ Valquíria M. Silva ${ }^{b}$ \\ and Eduardo $C_{\text {. }}$ Meurer ${ }^{\odot *, a, b}$
}

${ }^{a}$ Universidade Estadual de Maringá, 87020-900 Maringá-PR, Brazil

${ }^{b}$ Laboratório FENN de Espectrometria de Massas, Universidade Federal do Paraná, 86900-000 Jandaia do Sul-PR, Brazil

\begin{abstract}
This paper describes the monitoring of ethyl carbamate concentration in sugar cane spirit from industrial distilleries in Brazil. In total, 18 distilleries from Minas Gerais and São Paulo states were evaluated, with, a total of 336 samples from August 2017 to August 2019. The ethyl carbamate was analyzed using a previously validated mass spectrometric method. Analytical curves presented coefficient of determination $\left(\mathrm{R}^{2}\right)$ values higher than 0.99 , and quality control samples showed a relative standard deviation (RSD) below $9 \%$. Concentrations of ethyl carbamate ranged from not detected to $1608 \mu \mathrm{g} \mathrm{L}^{-1}$, with mean values of 294.2, 280.7 and $230.0 \mu \mathrm{g} \mathrm{L}^{-1}$ in 2017, 2018, and 2019, respectively. On average, 46, 44 and $69 \%$ of samples presented levels of ethyl carbamate below $210 \mu \mathrm{g} \mathrm{L}^{-1}$. A variety of factors may have led to distillery A having a low level (ca. $115 \mu \mathrm{g} \mathrm{L}^{-1}$ ) of ethyl carbamate, including controlled temperature, yeast strain, post-harvesting quality, sugar cane variety choice, and the treatment process on the sugar cane juice, which goes towards the addition of $\mathrm{Ca}(\mathrm{OH})_{2}$, heating and freezing. These results showed the importance of internal quality control, and that sugar cane juice treatment may be a way to decrease ethyl carbamate in the distilleries.
\end{abstract}

Keywords: ethyl carbamate, sugar cane spirit, quality control, Brazilian distilleries

\section{Introduction}

Ethyl carbamate, or urethane, is an organic compound naturally occurring on fermented food, such as fruit, cereals, sugar cane, shoyu, and wines. ${ }^{1-5}$ Despite its presence in food, it has been studied as a carcinogenic compound. It can be metabolized toward cytochrome P-450 to vinylurethane epoxide, which polymerizes deoxyribonucleic acid (DNA), causing cancer. Another route involves ethyl carbamate forming reactive oxygen species that lead to the depurination of DNA, resulting in disease. ${ }^{6}$

Sugar cane spirit is a highly appreciated alcoholic drink in Brazil (together with lemon juice, sugar, and ice, it is known as caipirinha) with an annual consumption of

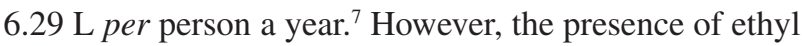
carbamate makes this a risk for the population. ${ }^{8,9}$ The permitted concentration of ethyl carbamate in sugar cane spirit was increased in 2014 from 150 to $210 \mu \mathrm{g} \mathrm{L}{ }^{-1} \cdot{ }^{10}$ Ethyl carbamate levels are defined in Brazil by the Ministry of

*e-mail: eduardo.meurer@ufpr.com
Agriculture, Livestock and Food Supply (MAPA), the Brazilian Regulation Agency for Food Control. ${ }^{11}$

Early studies showed that cyanogenic compounds, such as the amino acid arginine and urea, form cyanide ions which are the precursors of ethyl carbamate in the fermentation process. ${ }^{1}$ These nitrogen-containing compounds in high temperatures and acid medium of the distillation form cyanide ions, which triggers the formation of ethyl carbamate..$^{10}$ There are two alternative formation pathways for ethyl carbamate, one towards copper ion interactions with cyanide ions, forming a cyanate anion, and the subsequent reaction with ethanol, and another via the auto-oxidation of cyanide to cyanate, which forms ethyl carbamate with ethanol. ${ }^{12}$

The pressing concern of the levels of ethyl carbamate in sugar cane spirits in commercial products has led researchers to develop alternatives to reduce the levels of fermented drinks. These studies are related to physical, chemical, and biological methods. ${ }^{6}$ Borges et al. ${ }^{13}$ demonstrated that the selection of yeast strains might reduce ethyl carbamate. Bruno $\mathrm{et} \mathrm{al.} .^{14}$ found that distillation 
temperature adjustments were relevant to reduce the levels of ethyl carbamate in sugar cane spirits. Hashiguchi et al. ${ }^{15}$ observed that the addition of potassium metabisulfide and the reduction of dissolved oxygen reduced ethyl carbamate by $47 \%$. Alcarde et al. ${ }^{16}$ verified that double distillation removed $94-98.5 \%$ of ethyl carbamate from sugar cane spirit. It was observed that genetic engineering to inhibit arginase or to increase the methylation of urea from sugar cane reduced ethyl carbamate. ${ }^{6}$ Herein, we evaluate the concentrations of ethyl carbamate in sugar cane spirits from industrial plants for two years. It was observed that the impact of internal quality control on the chemical quality of the sugar cane spirit from distilleries may direct the buying process to improve the quality of the sugar cane spirits.

\section{Experimental}

\section{Chemicals}

Ethyl carbamate was purchased from Sigma-Aldrich (Saint Louis, MO, USA). Methanol (high performance liquid chromatography (HPLC) grade) was obtained from Vetec-Sigma-Aldrich (Duque de Caxias, Brazil). Trifluoroacetic acid and 18-crown-6 were purchased from Merck (Darmstadt, Germany). High purity Milli-Q water was used (Millipore, Bedford, MA, USA).

\section{Sample collection}

Three hundred and thirty-six samples of sugar cane spirit from 18 distilleries in Minas Gerais and São Paulo were obtained from the blending industry between August 2017 and August 2019, and analyzed as they arrived in the laboratory. The sugar cane varieties used to produce the sugar cane spirits were RB 867515, RB988082, RB92579, RB928064, RB835054 (Planalsucar-Ridesa, Araras, SP, Brazil).

\section{Ethyl carbamate quantification}

The quantification of ethyl carbamate was performed according to the quantification procedure proposed by Ribeiro et al. ${ }^{17}$ with some modifications. As there was no blank sample available to perform calibration curves, the standard addition method was used to find sugar cane spirit with the lowest ethyl carbamate concentration. Real samples with low concentration were used as the limit of quantification (ranging from 23 to $150 \mu \mathrm{g} \mathrm{L}^{-1}$ of ethyl carbamate) and base matrix to construct the analytical curves. Other levels were spiked with the standard addition of $150,300,450,600,750$, and $900 \mu \mathrm{g} \mathrm{L} \mathrm{L}^{-1}$ with $30 \mathrm{ppm}$ of 18 -crown- 6 and $0.1 \%$ of trifluoroacetic acid (TFA). The curves consisted of the lowest concentration of sugar cane spirit (for example, $23 \mu \mathrm{g} \mathrm{L}^{-1}$ of ethyl carbamate), and $23+150,23+300,23+450,23+600,23+750$ and $23+900 \mu \mathrm{g} \mathrm{L} \mathrm{L}^{-1}$. These samples were used to form an external analytical curve for the other real sugar cane spirits samples. All analyses were performed using the standard addition method, and every sample was injected into the mass spectrometer.

The conditions applied to utilize a sugar cane spirit as the lower concentration level included having a maximum residue level below $210 \mu \mathrm{g} \mathrm{L^{-1 }}$ of ethyl carbamate. A quality control sample was injected in triplicate on each analysis day. Quality control consisted of a previously analyzed real sample with a concentration ranging from 255 to $481 \mu \mathrm{g} \mathrm{L} \mathrm{L}^{-1}$ of ethyl carbamate. The carrier solution of methanol:18-crown-6: TFA (99.90:30 ppm:0.10, v/m/v) was pumped at $200 \mu \mathrm{L} \mathrm{min}{ }^{-1}$ with an injection volume of $5 \mu \mathrm{L}$. Mass spectrometric analyses were performed using a Quattro Premier XE (Waters, Milford, MA, USA) tandem quadrupole mass spectrometer, equipped with an electrospray (ESI) source. ESI was operated in the positive ionization mode (ESI+) at $3.5 \mathrm{kV}$, and MRM (multiple reaction monitoring) was set for a precursor ion of $\mathrm{m} / \mathrm{z} 90$ and an ion product of $m / z 62$. Coefficient of determination $\left(R^{2}\right)$ values higher than 0.98 were considered acceptable, and intraday and interday quality control results with a relative standard deviation (RSD, in percentage) below or equal to $15 \%$ were also accepted. ${ }^{18}$

\section{Results and Discussion}

\section{Quantitative analyses of ethyl carbamate}

The initial way to proceed with the investigations of real sugar cane spirit samples from distilleries was to find sugar cane spirits with an ethyl carbamate concentration as low as possible. The use of real sugar cane spirit was chosen to avoid different ionic suppression effects from synthetic and real matrices. ESI suffers from matrix effect, especially when the analyses are performed without liquid chromatography. ${ }^{19}$ The matrix effect usually reduces the ionization, making the signal non-constant; optimization and additive addition are typically used to mitigate these issues. To avoid the sensitivity differences of ethyl carbamate in a synthetic mixture of ethanol:water and real samples of sugar cane spirits, it was decided to use real samples as matrices, but they always included endogenous ethyl carbamate.

The results of using real sugar cane spirit as the matrix were that the analytical curves presented different linear 
ranges, as shown in Table 1. Initially, the concentrations of a range of sugar cane spirits were determined by standard addition, ${ }^{17}$ and some samples were separated as matrices to reduce the analytical curves. The decision regarding which sample was suitable for use as the lower ethyl carbamate concentration involved comparison to the maximum residue level (MRL) of $210 \mu \mathrm{g} \mathrm{L}^{-1}$. Ethyl carbamate was spiked in six more levels than the limit of quantification (LOQ) determined by standard addition. All analytical curves were constructed as on the first day of analysis (Table 1); level 1,56 $\mu \mathrm{g} \mathrm{L}^{-1}$ (determined by standard addition); level 2 , 56 plus $150 \mu \mathrm{g} \mathrm{L}^{-1}$ (spiked); level 3, 56 plus $300 \mu \mathrm{g} \mathrm{L}{ }^{-1}$; level 4, 56 plus $450 \mu \mathrm{g} \mathrm{L}^{-1}$; level 5, 56 plus $600 \mu \mathrm{g} \mathrm{L}^{-1}$; level $6,56{ }^{1}$ plus $750 \mu \mathrm{g} \mathrm{L}^{-1}$; level 7, 56 plus $900 \mu \mathrm{g} \mathrm{L}^{-1}$. Only the endogenous ethyl carbamate from the sugar cane spirit changed when different matrices were used. Table 1 shows the analytical parameters such as linear ranges, determination coefficients, the slope of the curves, intraday standard deviation (\%) of the quality control, and interday standard deviation (\%) of the mean of the analyses performed in 2019.

The recoveries were close to $100 \%$ with RSD (in percentage) according to MAPA, which allows an RSD of $20 \%$. The linearity of the direct injection multiple reaction monitoring methods (DI-MRM) was evaluated by constructing analytical curves with standards fortified into real sugar cane spirit samples with a low concentration of ethyl carbamate. The LOQ was analyzed in quintuplicate and each level was measured in triplicate. All of the coefficients of determination $\left(\mathrm{R}^{2}\right)$ were 0.99 . The angular coefficient from the analytical curves presented the same order of magnitude, despite the curve from 06/01/2019 that gave some unknown suppression; however, the $\mathrm{R}^{2}$, intraday RSD (in percentage), and interday showed adequate numbers, showing the robustness of the method. RSD values were calculated to evaluate the intraday repeatability $(n=3)$, which ranged from 1.14 to $11.63 \%$, and single point control samples were used to calculate interday precision using a median concentration of real sugar cane samples that was previously determined to be $8.0 \%$. These values were suitable to approve the analyses. It should be noted that the single point quality control had different concentrations, shown in Table 1, and presented proper values demonstrating good robustness.

Evaluation of ethyl carbamate in sugar cane spirit from Brazilian industrial distilleries during the two years

The concentration of ethyl carbamate from distilleries was evaluated during August 2017 and August 2019, for a total of 336 samples and 18 industries. The mean value of ethyl carbamate in sugar cane spirit was 294.2, 280.7 and $230.0 \mu \mathrm{g} \mathrm{L}^{-1}$ in 2017, 2018, and 2019, respectively. This showed that the quality control was effective to direct some critical points to improve the quality of the product acquired by the blender industry. Even with the mean level exceeding the MRL $\left(210 \mu \mathrm{g} \mathrm{L}^{-1}\right)$, the volume bought from the distilleries with low ethyl carbamate to blend after dilution, achieved levels of concentration below the legislation requirement.

Table 2 shows the results of the analyses of ethyl carbamate from 18 distilleries (from A to $\mathrm{R}$ ), from

Table 1. Analytical parameters evaluated in 2019

\begin{tabular}{|c|c|c|c|c|c|c|c|c|}
\hline Analysis date & $\begin{array}{c}\text { Linear range / } \\
\left(\mu \mathrm{g} \mathrm{L}^{-1}\right)\end{array}$ & $\mathrm{R}^{2}$ & Slope & Name & $\begin{array}{c}\text { Concentration of } \\
\text { ethyl carbamate / } \\
\left(\mu g \mathrm{~L} \mathrm{~L}^{-1}\right)\end{array}$ & $\begin{array}{l}\text { Intraday } \\
\text { RSD / \% }\end{array}$ & $\begin{array}{c}\text { Average } \\
\text { concentration / } \\
\left(\mu \mathrm{g} \mathrm{L}^{-1}\right)\end{array}$ & $\begin{array}{l}\text { Interday } \\
\text { RSD / \% }\end{array}$ \\
\hline $06 / 01 / 2019$ & $56-956$ & 0.99 & 0.316 & $\mathrm{~A} 2$ & 359 & 4.67 & \multirow{4}{*}{341} & \multirow{4}{*}{8} \\
\hline 06/06/2019 & $23-923$ & 0.99 & 6.1111 & $\mathrm{~A} 2$ & 304 & 2.88 & & \\
\hline 06/13/2019 & $150-900$ & 0.99 & 4.9568 & $\mathrm{~A} 2$ & 363 & 3.64 & & \\
\hline 06/19/2019 & $150-750$ & 0.99 & 3.7591 & $\mathrm{~A} 2$ & 340 & 3.63 & & \\
\hline $06 / 21 / 2019$ & $118.8-1018.8$ & 0.99 & 6.6159 & $\mathrm{~A} 1$ & 397 & 1.5 & \multirow{2}{*}{392} & \multirow{2}{*}{2} \\
\hline $06 / 27 / 2019$ & 118.8-1018.8 & 0.99 & 6.6159 & A1 & 387 & 1.6 & & \\
\hline $07 / 05 / 2019$ & $160-1060$ & 0.99 & 4.3379 & A4 & 255 & 3.06 & 255 & none \\
\hline $07 / 11 / 2019$ & $32-632$ & 0.99 & 6.3173 & A6 & 481 & 2.3 & 481 & none \\
\hline $07 / 19 / 2019$ & $150-1050$ & 0.99 & 4.0616 & A3 & 379 & 3.5 & \multirow{4}{*}{353} & \multirow{4}{*}{9} \\
\hline 07/26/2019 & $125-1025$ & 0.99 & 5.864 & A3 & 310 & 11.63 & & \\
\hline 08/01/2019 & 93-993 & 0.99 & 4.315 & A3 & 362 & 9.17 & & \\
\hline 08/07/2019 & 139-1039 & 0.99 & 5.6467 & A3 & 364 & 1.14 & & \\
\hline 08/16/2019 & 97-997 & 0.99 & 5.321 & A5 & 443 & 1.25 & 443 & none \\
\hline
\end{tabular}

$\mathrm{R}^{2}$ : coefficient of determination; RSD: relative standard deviation; A1-A6: quality control samples. 
Table 2. The number of samples for each distillery, minimum, maximum, and average of ethyl carbamate concentrations of the samples evaluated from August 2017 to August 2019

\begin{tabular}{|c|c|c|c|c|c|c|c|c|c|}
\hline \multirow[b]{2}{*}{ Distillery } & \multicolumn{3}{|c|}{2017} & \multicolumn{3}{|c|}{2018} & \multicolumn{3}{|c|}{2019} \\
\hline & $\begin{array}{c}\text { Number of } \\
\text { sample }\end{array}$ & $\begin{array}{c}\text { Min-Max / } \\
\left(\mu \mathrm{g} \mathrm{L}^{-1}\right)\end{array}$ & $\begin{array}{c}\text { Average / } \\
\left(\mu \mathrm{L} \mathrm{L}^{-1}\right)\end{array}$ & $\begin{array}{c}\text { Number of } \\
\text { sample }\end{array}$ & $\begin{array}{c}\operatorname{Min}-\operatorname{Max} / \\
\left(\mu g \mathrm{~L}^{-1}\right)\end{array}$ & $\begin{array}{c}\text { Average / } \\
\left.(\mu \mathrm{g} \mathrm{L})^{-1}\right)\end{array}$ & $\begin{array}{c}\text { Number of } \\
\text { sample }\end{array}$ & $\begin{array}{c}\text { Min-Max / } \\
\left(\mu \mathrm{g} \mathrm{L}^{-1}\right)\end{array}$ & $\begin{array}{c}\text { Average / } \\
\left(\mu \mathrm{g} \mathrm{L}^{-1}\right)\end{array}$ \\
\hline A & 9 & $23-278$ & 133 & 11 & $13-184$ & 103 & 20 & $61-236$ & 110 \\
\hline B & 31 & $36-727$ & 314 & 12 & $61-1444$ & 384 & 38 & $118-803$ & 343 \\
\hline $\mathrm{C}$ & 16 & $22-1572$ & 301 & 41 & $76-1122$ & 277 & 36 & $35-459$ & 345 \\
\hline $\mathrm{D}$ & 3 & $255-722$ & 446 & 5 & $84-271$ & 174 & 2 & $342-344$ & 343 \\
\hline $\mathrm{E}$ & 1 & 66 & none & 2 & $102-180$ & 141 & none & none & none \\
\hline $\mathrm{F}$ & 8 & $181-809$ & 339 & 4 & 171-1059 & 460 & 4 & $106-177$ & 138 \\
\hline G & 1 & 230 & none & 8 & $109-274$ & 168 & 3 & 103-169 & 90 \\
\hline $\mathrm{H}$ & 2 & $132-213$ & 172 & 9 & $22-1608$ & 301 & 2 & $326-493$ & 410 \\
\hline I & 2 & $157-187$ & 172 & 4 & $32-110$ & 83 & 4 & $110-324$ & 149 \\
\hline $\mathrm{J}$ & 5 & $167-453$ & 284 & 3 & $289-640$ & 408 & none & none & none \\
\hline K & 2 & $165-244$ & 204 & 2 & 560 & 560 & none & none & none \\
\hline $\mathrm{L}$ & 2 & 196-194 & 195 & 11 & $114-531$ & 206 & 1 & 168 & none \\
\hline M & 7 & $224-528$ & 388 & 8 & $168-1343$ & 451 & 3 & $35-189$ & 91 \\
\hline $\mathrm{N}$ & none & none & none & 1 & 1010 & none & none & none & none \\
\hline $\mathrm{O}$ & none & none & none & 1 & 509 & none & none & none & none \\
\hline $\mathrm{P}$ & none & none & none & 4 & $56-113$ & 87 & 5 & 56-159 & 97 \\
\hline Q & none & none & none & none & none & none & 2 & $218-293$ & 256 \\
\hline $\mathrm{R}$ & none & none & none & none & none & none & 1 & $<\mathrm{LOQ}$ & none \\
\hline
\end{tabular}

Min-Max: minimum and maximum of ethyl carbamate concentrations of the samples evaluated; LOQ: limit of quantification.

2017 to 2019, presenting the minimum and maximum concentrations for the year, as well as the average. The distilleries $\mathrm{A}, \mathrm{B}$ and $\mathrm{C}$ were the ones from which that the blender industry bought the sugar cane spirit more frequently. Distillery A presented the best ethyl carbamate concentrations and increased the selling of sugar cane spirit to the blender industry each year. In 2017, it started with nine lots, increasing to 20 lots in 2019, and the concentration in their lots decreased from $133 \mu \mathrm{g} \mathrm{L}^{-1}$ in 2017 to $103 \mu \mathrm{g} \mathrm{L}^{-1}$ in 2018 , elevating slightly in 2019 to $110 \mu \mathrm{g} \mathrm{L}^{-1}$, but remaining below the MRL. The results of distillery A were related to the control during the production chain, especially the sugar cane juice treatment that will be discussed later on the following topic.

It is evident a significant variation in the results between the distilleries, and even in the same industry. Almost all distilleries were able to obtain sugar cane spirit with low ethyl carbamate levels, as seen in the minimum values. One critical point reported by the blender industry was the reduced temperature control during the distillation process in some distilleries, which was studied by Bruno et al. ${ }^{14}$ Other critical points raised by the blender industry were the impact of the use of active yeasts, ${ }^{13}$ the post-harvesting quality, ${ }^{20}$ and the selection of sugar cane variety. ${ }^{21}$ Another critical way to decrease ethyl carbamate was the sugar cane juice treatment. ${ }^{5,22}$ From 18 distilleries, only A used this process. It was noticed that the concentration range reduced from 2017 to 2019 in distilleries C, D, F, and G. This showed that the quality control was efficient with regard to minimizing ethyl carbamate, and the efforts were mostly focused on temperature control.

Table 3 presents the evolution of the ethyl carbamate concentration in three ranges, below $200 \mu \mathrm{g} \mathrm{L} \mathrm{L}^{-1}$, between 200 and $400 \mu \mathrm{g} \mathrm{L}^{-1}$, and above $400 \mu \mathrm{g} \mathrm{L}^{-1}$. The percentage of sugar cane spirits with acceptable concentration levels increase from $42 \%$ in 2017 to $49 \%$ in 2018, and again to $52 \%$ in 2019. The range from 200 to $400 \mu \mathrm{g} \mathrm{L}-1$, which is a range that may be easily blended with low ethyl carbamate levels to reach acceptable concentrations reduced from $32 \%$ in 2017 to $28 \%$ in 2018, and increased to $41 \%$ in 2019. The variation in the percentage of the different ranges may be explained by two factors: the reduction in the levels of some distilleries, and the buying process directed towards distilleries with low ethyl carbamate. The range of ethyl carbamate concentrations above $400 \mu \mathrm{g} \mathrm{L}^{-1}$ decreased drastically, mostly from 2018 to 2019 , from 23 to $7 \%$, indicating the efficiency of the quality control of ethyl carbamate on the quality of sugar cane spirits. 
Table 3. Evolution of the ethyl carbamate concentration $<200 \mu \mathrm{g} \mathrm{L} \mathrm{L}^{-1}$, from 200 to $400 \mu \mathrm{g} \mathrm{L}^{-1}$, and $>400 \mu \mathrm{g} \mathrm{L}{ }^{-1}$, from 2017 to 2019

\begin{tabular}{lccc}
\hline \multirow{2}{*}{$\begin{array}{l}\text { Ethyl carbamate } \\
\text { range } /\left(\mu \mathrm{g} \mathrm{L}^{-1}\right)\end{array}$} & \multicolumn{3}{c}{ Sugar cane spirit samples / \% } \\
\cline { 2 - 4 } & 2017 & 2018 & 2019 \\
\hline$<200$ & 42 & 49 & 52 \\
$200-400$ & 32 & 28 & 41 \\
$>400$ & 16 & 23 & 7 \\
\hline
\end{tabular}

Distillery A was the one that presented the best results for quality and volume of production; and according to the industry, the results come from rigid controlling of temperature, yeast, post-harvesting, and sugar cane variety selection. Another action used to improve the quality of the sugar cane spirit was the sugar cane juice treatment that is presented below.

\section{Sugar cane juice treatment}

Distillery A was the reference in our study; the production practices used there were significantly different from those of other distilleries. The production practices employed by the distilleries in general resulted in the low ethyl carbamate concentrations observed over two years (Tables 1, 2 and 3). The good practices began in the selection of sugar cane varieties, post-harvesting control (less waiting time to grind cane), sugar cane juice treatment (Figure 1), yeast selection, and temperature control during the distillation process (around $88^{\circ} \mathrm{C}$ ). The sugar cane juice control was specifically used by distilleries to reduce ethyl carbamate levels in the sugar cane spirit. The chemical process employed targets cyanide anions, a precursor species that reacts with ethanol on the distillation column to form ethyl carbamate. ${ }^{6}$

Figure 1 shows the process of treating sugar cane juice used by distillery A to decrease cyanide anion levels; a similar treatment was discussed by Ribeiro et al..$^{5}$ The process starts with a $\mathrm{pH}$ adjustment to ca. 6.25 , followed by the addition of hydrated virgin lime; after this, the temperature is raised to $80{ }^{\circ} \mathrm{C}$, reduced to $36{ }^{\circ} \mathrm{C}$, and centrifuged. Calcium cations are known to be chelators and precipitate compounds with electron excess (negative charges); together with the cellulose turbidity, they are co-precipitated with cyanide anions.

\section{Conclusions}

An overall reduction of the concentration levels of ethyl carbamate was verified in sugar cane spirits from 18 distilleries over the years of 2017 and 2019. The percentage of sugar cane spirits with acceptable concentration levels increased from $42 \%$ in 2017 to $48 \%$ in 2018 , and again to $52 \%$ in 2019 . It was possible by the analysis performed, the industry to improve the quality of sugar cane spirits during the time directed by this research and used in a blending industry, directly impacting millions of people. It has an impact on both health and economy, since the blending industry produces around 3,000,000 bottles of blended sugar cane spirits and other drinks per month.

\section{Acknowledgments}

The authors are grateful to the Waters Company, Forquimica Company, Jamel Company, and UFPR for financial support.

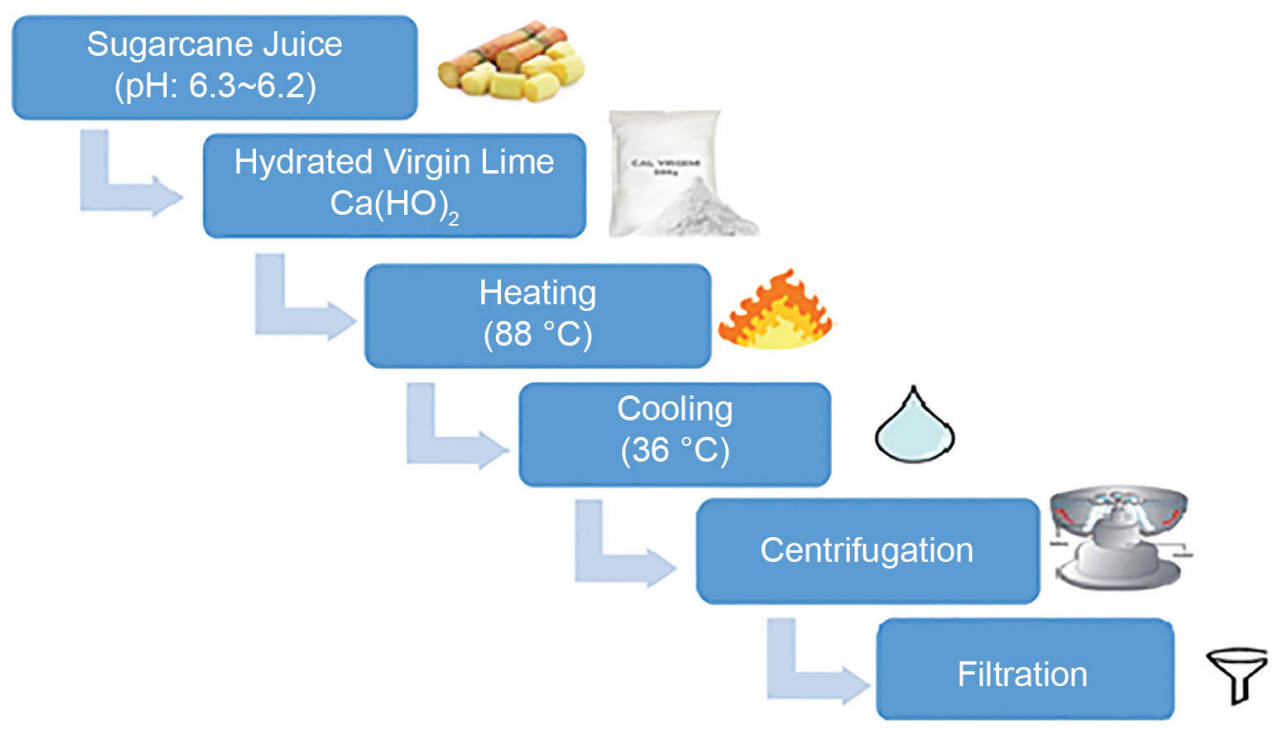

Figure 1. Sugar cane juice treatment used in distillery A. 


\section{Author Contributions}

Rafaela C. Bueno and Angélica P. P. Tonin performed the experiments. Camila B. Poliseli and Nayane B. M. Sinosaki formatted the article. Eduardo C. Meurer, Jesuí V. Visentainer, Valquiria M. Silva, Cláudio C. Oliveira and Marcos A. S. Ribeiro were responsible for the conceptualization. Rafaela C. Bueno, Eduardo C. Meurer and Valquíria M. Silva wrote the article. Rafaela C. Bueno, Angélica P. P. Tonin and Eduardo C. Meurer had the main idea. All authors discussed the results and contributed to the final manuscript.

\section{References}

1. Baffa Jr., J. C.; Mendonça, R. C. S.; Pereira, J. M. A. T. K.; Pereira, J. A. M.; Soares, N. F. F.; Food Chem. 2011, 129, 1383.

2. Li, G.; Zhong, Q.; Wang, D.; Zhang, X.; Gao, H.; Shen, S.; Food Control. 2015, 56, 169.

3. Ryu, D.; Choi, B.; Kim, N.; Koh, E.; Food Chem. 2016, 211, 770.

4. Chen, D.; Ren, Y.; Zhong, Q.; Shao, Y.; Zhao, Y.; Wu, Y.; Food Control. 2017, 72, 283.

5. Ribeiro, M. L. D.; Ferreira, O. E.; Teixeira, V.; Mutton, M. A.; Mutton, M. J. R.; Rev. Cienc. Agron. 2017, 48, 458.

6. Zhao, X.; Guocheng, D.; Zou, H.; Fu, J.; Zhou, J.; Zhao, J. C.; Trends Food Sci. Technol. 2013, 32, 97.

7. Silva, J. H. N.; Verruma-Bernardil, M. R.; Margarido, L. A. C.; Oliveira, A. L.; Rev. Cienc. Agrar. 2019, 42, 547.

8. Lachenmeier, D. W.; Lima, M. C. P.; Nóbrega, I. C. C.; Pereira, J. A. P.; Kerr-Corrêa, F.; Kanteres, F; Rehm, J.; BMC Cancer 2010, 10, 266.

9. Nóbrega, I. C. C.; Pereira, J. A. P.; Paiva, J. E.; Lachenmeier, D. W.; Food Chem. 2011, 127, 1243.

10. Bortoletto, A. M.; Alcarde, A. R.; Beverages 2016, 2, 2.

11. Ministério da Agricultura, Pecuária e Abastecimento (MAPA); Instrução Normativa No. 28, de 08/08/2014; Diário Oficial da União (DOU), Brasília, No. 152, p. 7. Available at http://www.lex.com.br/legis_25819224_INTRODUCAO_ NORMATIVA_N_28_DE_AGOSTO_DE_2014.ASPX, accessed in February 2020.

12. Aresta, M.; Boscolo, M.; Franco, D. W.; Food Chem. 2001, 49, 2819.

13. Borges, G. B. V.; Gomes, F. C. O.; Badotti, F.; Silva, A. L. D.; Machado, A. M. R.; Food Control. 2014, 37, 380.

14. Bruno, S. N. F.; Vaitsman, D. S.; Kunigami, C. N.; Brasil, M. G.; Food Chem. 2007, 104, 1345.

15. Hashiguchi, T.; Horii, S.; Izu, H.; Shigetoshi, S.; Biosci., Biotechnol., Biochem. 2010, 74, 2060.

16. Alcarde, A. R.; Souza, L. M.; Bortoletto, A. M.; J. Inst. Brew. 2012, 118, 352.

17. Ribeiro, M. A.; Tonin, A. P. P.; Poliseli, C. B.; Oliveira, C. C.; Visentainer, J. V.; Silva V. M.; Meurer, E. C.; Food Anal. Methods 2019, 12, 69.

18. Agência Nacional de Vigilância Sanitária (ANVISA); Resolução No. 899; Guia para Validação de Métodos Analíticos e Bioanalíticos, Diário Oficial da União (DOU), Brasília, No. 104, de 02/06/2003. Available at http://portal.anvisa.gov. br/documents/10181/2718376/RE_899_2003_COMP.pdf/ ff6fdc6b-3ad1-4d0f-9af2-3625422e6f4b, accessed in February 2020.

19. Nanita, S. C.; Kaldon, L. G.; Anal. Bioanal. Chem. 2015, 408, 23.

20. Filho, J. H. O.; Bortoletto, A. M.; Alcarde, A. R.; Braz. J. Food Technol. 2016, 19, 16.

21. Oliveira, D. C.; Oliveira, M. W.; Pereira, M. G.; Gomes, T. C. A.; Silva, V. S. G.; Oliveira, T. B. A.; Afr. J. Agric. Res. 2017, $12,260$.

22. Araújo, F. A. D.; Cienc. Tecnol. 2007, 1, 1, available at http:// www.unicap.br/revistas/revista_e/artigo7.pdf, accessed in February 2020.

Submitted: November 17, 2019

Published online: February 27, 2020 